\title{
Consumer Perception towards Big Basket in Ahmedabad Region
}

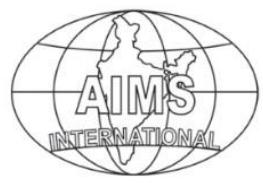

DOI: $10.26573 / 2020.14 .1 .4$

Volume 14, Number 1

January 2020, pp. 53-62

\author{
Neha Upadhyay \\ Ahmedabad, India \\ Sal Institute of Management \\ (nehaupadhyay1106@gmail.com)
}

As the e-commerce sector is growing in the economy, we can see its presence and impact on various segments. E-commerce has eased the way business transactions are carried out. E-grocery is emerging as an exceedingly huge approach. The Researcher has administrated the cross sectional survey in Ahmedabad city and collected the data from the respondents who are availing the services of Big Basket. Structured Questionnaire has been applied and targeted to those clusters where the consumers are availing such services. A sample size of 416 respondents are targeted from the various areas of Ahmedabad like Science City, Judges Bungalow, South Bopal, Shahibaug, Maninagar, Godrej Garden City, Satellite, Prahladnagar and Jodhpur. The study tries to focus on the categorical variables like gender, age, occupation, income, education and qualification and various questions related to purchase behaviour. The researcher also focuses on understanding the opinion of consumers with respect to perceived price, perceived quality, perceived level of services and perceived benefits. Attitude Likert Scale has been applied to understand the intensity of big basket online consumers on different statements framed within the questionnaire. Researcher also considers dependent variable as an overall outcome of the above mentioned independent variables.

\section{Introduction}

Over the past two decades, the Indian e-commerce sector has witnessed a rising trend. Major factors that have led to this rise are increasing net convenience and internet penetration. Also, growing acceptability of on-line payments and favorable demographics has modified the approach through which corporations communicate, act and do business with customers. It has altered the approach of how the Indian ecommerce sector works. The buying behavior of people has changed significantly from brick and mortar to click and mortar or what we call as e-tailing. In the early years e-commerce was considered to be an aid to the business. In the meantime it has become more or less business enabler (Mohapatra 2013, pp.10-12). The emergence of e-commerce also significantly lowered barriers to entry in selling many types of goods; many small home-based proprietors are able to use the internet to sell the goods. Established suppliers had to close their shops and had to change their business model to an E-commerce model to stay profitable and in the business. 


\section{E-Grocery}

Out of all the sectors that have seen the rise of e-commerce, grocery is one which has led to quite a surprising business model. If we look back to the past, groceries have always been bought through physical stores. The idea of touching and feeling the product before purchasing it has been the psychology of Indian consumers. So when the concept of e-grocery was introduced there was a lot of skepticism that surrounded it. Even if we look today's scenario e-grocery still remains at the stage of infancy and is growing slowly and gradually. There are certain advantages of egrocery as any other e-commerce sector like faster delivery, accessibility, offers and discounts. While on the other hand it also struggles with certain limitations like difficulty in penetrating in small towns, lack of awareness among homemakers, freshness of fruits and vegetables, etc. The major players dominating the market currently are Big Basket and Grofers.

Big Basket launched in 2011 is the largest online grocery store in Asian nation. The success of Big Basket is attributed to a number of factors like offering wide variety of product range at lowest prices and efficient services. The flexibility of offering delivery time is considered to be a USP of Big Basket. The delivery time brackets start from morning 6:00 am to evening 9:00 pm. Big Basket has recently crossed 10 million customers mark and is clocking close 1 lakh orders per day. With its presence in 30 towns and cities in India it is now planning to dig deeper into the cities it already has a foothold in, rather than focusing on expansion into more cities.

Table 1 Top Online Grocery Markets in Asia by 2022

\begin{tabular}{|l|c|c|c|c|}
\hline \multicolumn{1}{|c|}{ Country } & $\begin{array}{c}\text { Market Share } \\
\text { of Online }\end{array}$ & $\begin{array}{c}\text { Market Share of } \\
\text { Online Grocery }\end{array}$ & $\begin{array}{c}\text { Online Grocery } \\
\text { Sales Growth 2017- }\end{array}$ & $\begin{array}{c}\text { Increase in Online } \\
\text { Grocery Sales }\end{array}$ \\
\hline China & $3.8 \%$ & $11.1 \%$ & $31 \%$ & $136.8 \mathrm{bn}$ \\
\hline Japan & $7.0 \%$ & $9.8 \%$ & $7.9 \%$ & $14.4 \mathrm{bn}$ \\
\hline South Korea & $8.1 \%$ & $13.6 \%$ & $15.7 \%$ & $9.9 \mathrm{bn}$ \\
\hline India & $0.05 \%$ & $0.6 \%$ & $87.0 \%$ & $5.0 \mathrm{bn}$ \\
\hline Indonesia & $0.1 \%$ & $1.5 \%$ & $85.0 \%$ & $4.5 \mathrm{bn}$ \\
\hline Taiwan & $4.5 \%$ & $7.3 \%$ & $14.9 \%$ & $1.7 \mathrm{bn}$ \\
\hline Singapore & $2.5 \%$ & $7.8 \%$ & $29.0 \%$ & $0.4 \mathrm{bn}$ \\
\hline
\end{tabular}

Source: IGD Asia Research

It is expected that over the coming years the digital footprint in the Asian countries is going to be on rise and it is expected that the market share of online grocery in India by 2022 will be $0.6 \%$. The source and evidence for the same can be visible from the Table 1 . Hence it is necessary to identify and study the perception of consumers towards e-grocery so as to make necessary changes in the business model accordingly.

\section{Literature Review}

S. Sathiyaraj, A. Santosh Kumar and A. K. Subramani have conducted a research in Chennai targeting 200 respondents through Google forms. The basic purpose of this research was to understand consumer perception towards online grocery shopping in Chennai. The major findings suggest that a larger number of people prefer online shopping due to best price that they get and also that the demographic variables don't have a significant impact on customer satisfaction. 
Another significant contribution was made by George Adamidis (2006) where the survey was conducted in Nicosia. The instrument used for the survey was a self administered questionnaire and the findings indicated that the consumers were not very receptive of the concept of e-grocery due to the element of risk involved in shopping online. It was further concluded that quality of the product and money back guarantee can be implemented and demonstrated as a major risk relievers to promote online grocery shopping among the consumers. However the paper fails to elaborate the element of risk and also what are the other factors that restrict the adoption of online grocery shopping.

US researchers at the University of Maine have been observing the consumer behavior towards purchase of food and drinks online. The major factor that influences the purchase is the quality and variety of products available online as compared to locally available products. Though it is significant to analyze that whether the results of food and drink could be compared to that of online grocery shoppers or not.

Bell et al. (1998) concludes in their research paper that the higher amount of delivery fees charged by the e-tailers makes it difficult for them to avail its services. The study focuses on the fixed and variable cost structure of the consumers who purchase groceries online. The study further compares the cost structure with the offline cost and it is concluded that a number of costs like petrol, parking, travel time, etc are much more as compared to the delivery charges that a consumer has to pay. And it was concluded that there isn't much difference between the offline cost and the delivery charges hence the customers shouldn't deter from online grocery shopping.

A study on frequency of online grocery purchase was conducted by Radka Bauerová to measure the effectiveness of online services and to analyze consumer decision making. The study focused on the number of times customer used online grocery for purchase and also for the different category of products for which the purchase is made. The purpose of the research paper was to identify the set of products which are preferred by the consumers for purchasing online and whether there are any repeat purchases for the same. On the basis of the literature review four factors have been identified for measuring consumer perception towards big basket that are perceived price, quality, service and benefits. All four independent factors are further analyzed on 5-6 statements to check the effectiveness and impact on the dependent factor.

\section{Research Process}

The Researcher has administrated the cross sectional survey in Ahmedabad city and collected the data/opinion from the respondent those are availing the services of Big Basket. Structured questionnaire was applied and targeted to those clusters where the consumers are availing such services. A total of 416 Respondents were targeted from the various areas of Ahmedabad like Thaltej, Science city, Judges Bunglow, South Bopal, Shahibaug, Maninagar, jagatpur, godrej garden city, satellite, Prahladnagar and Jodhpur. Here the researcher tries to focus on the categorical variables like gender, age, occupation, income, education and qualification and various questions related to purchase behaviour. The researcher also focuses to understand the opinion of consumers with respect to perceived price (OF1), perceived quality (OF2), perceived level of services (OF3) and perceived benefits (OF4). Here researcher has 
applied attitude Likert scale to understand the intensity of big basket online consumers on different statements framed with questionnaire instrument. Researcher also considers dependent variable as an overall outcome of the above mentioned independent variables. The study primarily focuses on following research objectives:

- To study the various factors related to online purchase with respect to Big Basket

- To measure the impact of various factors with reference to online purchase on the overall purchase of consumers.

\section{Research Design}

This is a cross sectional attempt by researcher to understand the level of perception regarding the various aspects like perceived quality, perceived price, perceived level of service and perceived benefits. Here researcher evaluates the impact of all independent variables on dependent variable i.e. overall outcomes. This is unique attempt made by researcher trying to derive new conclusions with fresh collection of data in different geographical region, demographic profile and with different techniques. Therefore the descriptive cross sectional research is obvious choice of researcher.

\section{Sampling Design}

The collection of data has been done using structured questionnaire and applying purposive non-probability sampling. Researcher is looking for the opinion from the respondents who buy the goods online from big baskets. Therefore, there is a specific purpose to select the respondent to understand the opinion.

\section{Analytical Tools and Techniques}

Researcher applied the tools like reliability, descriptive and hierarchical regression to understand the most influential factors amongst the all independent factors. Here researcher has applied summated scale to derive the value of independent and dependent variables. SPSS 25 is used for the statistical analysis purpose.

\section{Analysis}

The data of 416 respondents was collected with structured questionnaires, mainly entire questionnaire design was based on 23 different statements related to four independent variables like perceived price, quality, services and benefits. The purpose of research is to understand the impact of four independent variables on overall outcomes on consumer's perception. The first thing was to analyze the internal consistency of structured questionnaire, whether respondents understand the meaning of the statements and they are consistent while giving the response of the various statements. Hence the researcher has applied the tool Cronbach's alpha to evaluate internal consistency of opinion given by the respondents. Reliability Table 4.1 indicates the value of Cronbach alpha as 0.905 which considered desirable. It means that the study does not violate the assumption of reliability.

\section{Reliability Statistics}

Table 4.1

\begin{tabular}{|c|c|c|}
\hline Cronbach's Alpha & Cronbach's Alpha Based on Standardized Items & N of Items \\
\hline .905 & .905 & 23 \\
\hline
\end{tabular}


To achieve the basic purpose of this research, here researcher want to measure the impact of various independent factors like perceived price, quality, services and benefits on overall outcomes on consumer perception with respect to big basket. Therefore researcher applies multiple regressions to evaluate the impact. The initial step for multiple regressions is to understand whether multiple regression models of independent variables and dependent variable is valid or not.

Model Summary

Table 4.2

\begin{tabular}{|c|c|c|c|c|c|c|c|c|c|c|}
\hline Model & $\mathrm{R}$ & $\begin{array}{c}\mathrm{R} \\
\text { Square }\end{array}$ & $\begin{array}{c}\text { Adjusted } \\
\text { R Square }\end{array}$ & $\begin{array}{c}\text { Std. Error } \\
\text { of the } \\
\text { Estimate }\end{array}$ & $\begin{array}{c}\text { R Square } \\
\text { Change }\end{array}$ & $\begin{array}{c}\text { F } \\
\text { Change }\end{array}$ & df1 & df2 & $\begin{array}{c}\text { Sig.F } \\
\text { Change }\end{array}$ & $\begin{array}{c}\text { Durbin } \\
\text { Watson }\end{array}$ \\
\hline 1 & $.719^{\mathrm{a}}$ & .516 & .512 & .38172 & .516 & 109.720 & 4 & 411 & .000 & 2.048 \\
\hline
\end{tabular}

$\mathrm{Y}=\mathrm{a}+\beta 01 \times 1+\beta 02 \times 2+\beta 03 \times 3+\beta 04 \times 4+€$

where $Y$ denotes overall purchase outcomes, a denotes constant, $\beta 01, \beta 02, \beta 03, \beta 04$ are the respective regression coefficient on overall perception outcomes and $\mathrm{x} 1, \mathrm{x} 2$, $\mathrm{x} 3, \mathrm{x} 4$ denote independent factors like perceived price, quality, level of services and benefits respectively and $€$ denotes error term. In the model summary (Table 4.2) it is clearly indicated that sig value is .000 which is less than 0.05 it indicates that all the independent variables sufficiently explain the variance on dependent variables. Considering model summary value of $\mathrm{R}$ is .719 and value of coefficient of determination $\mathrm{R}^{2}$ is .516 . This means $51.60 \%$ changes in consumers purchase because of all four independent variables price, quality, level of services and benefits while remaining $48.40 \%$ changes occurs because of all remaining factors. In the second column value of adjusted $\mathrm{R}^{2}$ is very close to coefficient of the determination because all the four independent variables significantly contribute in the changes of dependent variable. The Durbin Watson test value indicates 2.048 which almost touch the benchmark that means researcher does not violate the assumption of serial auto correlations. The value of coefficient of determination indicate that variance explained by four independent factors contribute more than unexplained variance.

ANOVA $^{\mathrm{a}}$

Table 4.3

\begin{tabular}{|l|l|c|c|c|c|c|}
\hline \multicolumn{2}{|c|}{ Model } & Sum of Squares & df & Mean Square & F & Sig. \\
\hline \multirow{2}{*}{1} & Regression & 63.950 & 4 & 15.987 & 109.720 & $.000^{\mathrm{b}}$ \\
\cline { 2 - 7 } & Residual & 59.887 & 411 & .146 & & \\
\cline { 2 - 7 } & Total & 123.837 & 415 & & & \\
\hline
\end{tabular}

Coefficients $^{\mathrm{a}}$

From Table 4.4 researcher wants to understand the individual impact of each factors on dependent variable, since this is cross sectional research therefore researcher emphasize on unstandardized coefficient. The coefficient table first column indicate the value of constant and respective regression coefficients of 
independent variables shows their relative impact on dependent variable overall purchase outcomes.

Table 4.4

\begin{tabular}{|c|c|c|c|c|c|c|c|c|}
\hline & \multirow[t]{2}{*}{ Model } & \multicolumn{2}{|c|}{$\begin{array}{l}\text { Unstandardized } \\
\text { Coefficients }\end{array}$} & \multirow{2}{*}{$\begin{array}{c}\text { Standardized } \\
\text { Coefficients }\end{array}$} & \multirow[t]{2}{*}{$\mathbf{t}$} & \multirow[t]{2}{*}{ Sig. } & \multicolumn{2}{|c|}{$\begin{array}{c}\text { Collinearity } \\
\text { Statistics }\end{array}$} \\
\hline & & B & Std. Error & & & & Tolerance & VIF \\
\hline & (Constant) & .934 & .145 & & 6.433 & .000 & & \\
\hline & $\mathrm{OF} 1$ & .177 & .039 & .200 & 4.560 & .000 & .614 & 1.629 \\
\hline 1 & $\mathrm{OF} 2$ & .326 & .040 & .351 & 8.063 & .000 & .622 & 1.607 \\
\hline & OF3 & .140 & .046 & .166 & 3.075 & .002 & .405 & 2.468 \\
\hline & OF4 & .139 & .042 & .172 & 3.347 & .001 & .447 & 2.238 \\
\hline
\end{tabular}

a. Dependent Variable: OPER

H1: There is a significant impact of perceived price on overall purchase outcomes

H2: There is a significant impact of perceived quality on overall purchase outcomes

H3: There is a significant impact of perceived level of services on overall purchase outcomes

H4: There is a significant impact of perceived benefits on overall purchase outcomes

Here the fifth column in the coefficient table indicates the significant value for each independent factor is $.000, .000, .002$ and .001 respectively all of which are less than 0.05 hence it shows that all the independent variables have a significant impact on the dependent factor, which is overall purchase outcome.

$\boldsymbol{\beta 0 1}=$ when price changes 1 unit it creates .177 changes in the value of overall perception

$\boldsymbol{\beta 0 2}=$ when quality changes 1 unit it creates .326 changes in the value of overall perception

$\boldsymbol{\beta 0 3}=$ when level of services changes 1 unit it creates .140 changes in the value of overall perception

$\boldsymbol{\beta 0 4}=$ when benefits changes 1 unit it creates .139 changes in the value of overall perception

If we put these values in to the regression equation it would be as follows

$\mathrm{Y}=\mathrm{a}+\beta 01 \times 1+\beta 02 \times 2+\beta 03 \times 3+\beta 04 \times 4+€$ can be computed as under,

$Y=.934+.177$ (Price) +.326 (Quality) +.14 (Service level) +.139 (benefits) $+€$

From the above value, it can be analyzed that quality is the most influential independent variable affecting the dependent variable followed by price, level of services and benefits. Majority of the respondents have strongly agreed that the product that appears on the portal and the one that is delivered should always be the same. This means that the duplication or fake products should be avoided on Big Basket. Also the respondents agreed that many perishable products are also bought online packaging of product is very important as it helps to maintain the product quality.

Another most influential factor is price where most of the respondents believed that purchasing groceries online should avail them best price, offers and discounts. Respondents also feel that there should be no hidden charges levied on them and at times weekly or monthly deals should be offered where they can get products as value for money offer. Also when the overall perception of the consumers was 
measured it was analyzed that majority of the respondents agreed that the process of ordering should be user friendly and the range and variety of products offered should be unique and attractive. The security and ease of use are two factors which are of utmost importance for the consumers to transact online. With the majority of its users falling in the Generation Y category, it is necessary for the Big Basket to make the model as user friendly as possible and bring about transparency in the process. Also, it was found during the study that the number of people purchasing groceries online as frequently as weekly is very less. It means that still people are following the conventional buying behavior of purchasing groceries monthly.

As far as benefits are concerned it was found that consumers preferred to be valued and expect benefits over a period of time as they become loyal customers. The benefits can be something as tangible as gifts and vouchers to the members or intangible benefits like reward points, upgrading the membership type and so on. Percentage based discounts are also highly attractive feature to generate customers. All the independent factors have a greater degree of influence on the final purchase outcome and hence they should be catered by Big Basket.

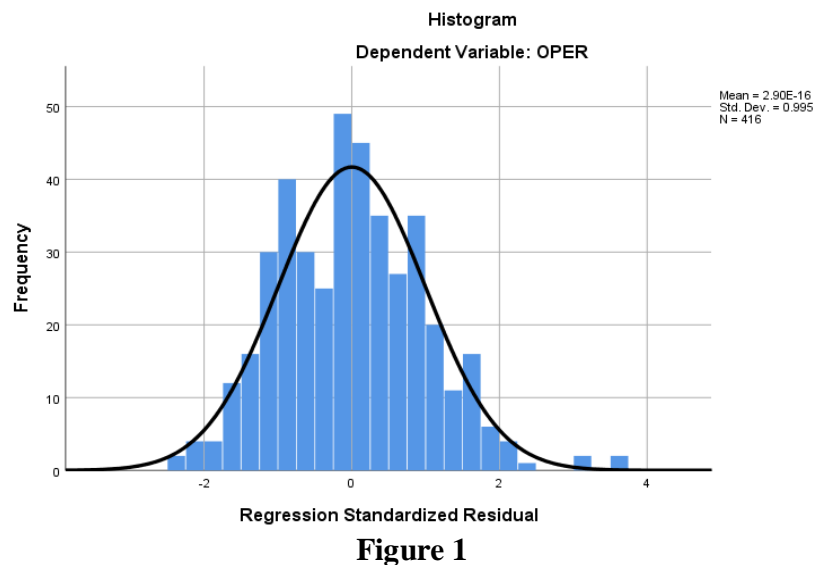

Here it is equally important to evaluate whether the data is not affected by the issue of multi-collinearity, hence the tolerance and VIF is the obvious choice of statistical tools to address the issue of multi collinearity. If we consider the last two columns of tolerance and VIF, all the values of independent variables of tolerance is more than .10 and all the values of VIF is less than 10. It indicates that the researcher has not violated the assumption of multi collinearity. With the help of Figure 1the researcher frames the Normality chart with Histograms. Shape of the chart is almost bell shape indicating that the researcher does not violate the assumption of normality.

\section{Recommendations and Conclusion}

The analysis can be concluded by saying that all the independent factors that have been identified and studied have significant influence on the overall perception of the consumers which in turn influences their buying behavior. As quality is a major influencing factor, Big Basket should ensure that all the quality parameters like expiry date products, packaging and damaged goods should be controlled to develop 
the trust of consumers. Also to take advantage of second most influencing factor price, Big Basket should collaborate with maximum payment vendors to offer best price and discounts to its members. Also the benefits provided to the members should be distinct on the volume of purchase to provide varied benefits and privileges. Big Basket is already providing free delivery services and that too at varied time slots but in order to make the delivery process more efficient it should ensure shorter waiting time and training delivery personnel. In order to break the conventional buying behavior of buying groceries monthly, Big Basket should launch lucrative weekly deals which would prompt the buyers to improve the frequency of purchase.

If we look at the current scenario of Indian e-commerce sector the picture looks quite bright. Also the e-grocery sector is still developing and is currently dominated by two major players so there are chances that many new players might join in. Hence in order to maintain its position and to survive in case of tough competition Big Basket should work on its USP i.e offering varied and unique products like exotic vegetables and fruits, vast delivery options and building strong member base. Consumers are not able to understand that apart from monetary benefits online grocery shopping also helps them in completing the purchase process hassle free by avoiding standing in long payment lines and carry all the weight to home. Consumers might also prefer Big Basket if it offers packaging variants to the consumers. The physical stores have the problem of inventory and at times can accommodate products in certain packaging only. Big Basket can overcome this limitation of physical stores and try to leverage it by offering packing variants from smallest to the maxim size available. The business

\section{References}

1. Sathiyaraj, S \& Santhosh Kumar, A \& Subramani, A K. (2015). Consumer Perception towards Online Grocery Stores, Chennai.

2. Shah, Neer. (2019). Understanding the Buying Behavior of Women towards Online Grocery Shopping in Ahmedabad. 10.13140/RG.2.2.28409.72806.

3. Rajagopalan, Kavitha. (2017). A Study on Consumers acuity towards online grocery shopping.

4. Hand, Chris \& Dall'Olmo Riley, Francesca \& Harris, Patricia \& Singh, Jaywant \& Rettie, Ruth. (2009). Online grocery shopping: The influence of situational factors. European Journal of Marketing. 43. 10.1108/03090560910976447.

5. Davies, Alec \& Dolega, Les \& Arribas-Bel, Daniel. (2019). Buy online collect in-store: exploring grocery click \& collect using a national case study. International Journal of Retail \& Distribution Management. 10.1108/IJRDM-012018-0025.

6. Van Droogenbroeck, Ellen \& Van Hove, Leo. (2019). Triggered or evaluated? A qualitative inquiry into the decision to start using e-grocery services. The International Review of Retail, Distribution and Consumer Research. 1-20. 10.1080/09593969.2019.1655085.

7. Kaur, Anupriya \& Thakur, Preeti. (2019). Determinants of Tier 2 Indian consumer's online shopping attitude: a SEM approach. Asia Pacific Journal of Marketing and Logistics. ahead-of-print. 10.1108/APJML-11-2018-0494. 
8. Bauerová, Radka. (2018). Consumers' Decision-Making in Online Grocery Shopping: The Impact of Services Offered and Delivery Conditions. Acta Universitatis Agriculturae et Silviculturae Mendelianae Brunensis. 66. 12391247. 10.11118/actaun201866051239.

9. Nurfatiasari, Safrani \& Aprianingsih, Atik. (2017). A Pilot Study of Technology Adoption: An Analysis of Consumers' Preference on Future Online Grocery Service. The Asian Journal of Technology Management (AJTM). 10. 74-89. 10.12695/ajtm.2017.10.2.3.

10. Mkansi, Marcia \& Eresia-Eke, Chuks \& Oyetola, Emmannuel. (2018). Egrocery Challenges and Remedies: Global Market Leaders Perspective. Cogent Business \& Management. 5. 10.1080/23311975.2018.1459338.

11. Martín, Juan \& Pagliara, Francesca \& Román, Concepción. (2019). The Research Topics on E-Grocery: Trends and Existing Gaps. Sustainability. 11. 321. 10.3390/su11020321.

12. Elms, Jonathan \& de Kervenoael, Ronan \& Hallsworth, Alan. (2016). Internet or store? An ethnographic study of consumers' internet and store-based grocery shopping practices. Journal of Retailing and Consumer Services. 32. 234-243. 10.1016/j.jretconser.2016.07.002.

13. Trinh, Giang \& Anesbury, Zachary \& Driesener, Carl. (2017). Has behavioural loyalty to online supermarkets declined?. Australasian Marketing Journal (AMJ). 10.1016/j.ausmj.2017.10.005.

14. A. Morganosky, Michelle \& Cude, Brenda. (2000). Consumer Response to Online Grocery Shopping. International Journal of Retail \& Distribution Management. 28. 17-26. 10.1108/09590550010306737.

15. Ali, Sanober \& Saleem, Mariam \& Ahmed, Mohammad Ekhlaque \& Khan, Marium \& Shah, Neha \& Rafiq, Saad. (2017). Models for Online Grocery Shopping - A Study of Pakistani Online Market. Journal of Internet and eBusiness Studies. 2017. 1-15. 10.5171/2017.839022.

16. Hanus, Gabriela. (2016). CONSUMER BEHAVIOUR DURING ONLINE GROCERY SHOPPING. CBU International Conference Proceedings. 4. 010. 10.12955/cbup.v4.737.

17. K.C., Saban \& Timalsina, Arun. (2016). Consumer Attitudes Towards Online Grocery Shopping in Kathmandu Valley.

18. Danaher, Peter \& Wilson, Isaac \& A. Davis, Robert. (2003). A Comparison of Online and Offline Consumer Brand Loyalty. Marketing Science. 22. 461-476. 10.1287/mksc.22.4.461.24907.

19. Hult, Tomas \& Nidhi Sharma, Pratyush \& Morgeson, Forrest \& Zhang, Yufei. (2018). Antecedents and Consequences of Customer Satisfaction: Do They Differ Across Online and Offline Purchases?. Journal of Retailing. 10.1016/j.jretai.2018.10.003.

20. Rajesh, Rupali. (2019). Assessing the impact of Online Grocery Shopping in Mumbai. 9. 884-889.

21. Vijayasarathi. R, Predicting consumer intentions to use online shopping: the case for an augmented 


\begin{abstract}
About Our Author
Neha Upadhyay specializes in Finance and Marketing area. Prior to her current position at Sal Institute of Management she has worked as an Assistant Professor for more than 5 years, as an Academic Associate in Communication Area at Indian Institute of Management, Ahmedabad and has worked as a visiting faculty at IGNOU for two years. Apart from academics, she also has an industry experience of two years where she has worked with Talwalkars Better Value Fitness as a Branch Manager and was working as Head-Operations at Samay Group of Companies. She has to her credit participation in various national and international conferences. Currently she is pursuing her M.Phil and her research interests include consumer psychology and B-2B marketing.
\end{abstract}

